\title{
LIGHT REVEALING ARCHITECTURE FORM - THE ROLE OF LIGHT IN CONTEMPORARY INTERPOLATION
}

\author{
Sanja Paunović-Žarić* \\ University of Montenegro, Faculty of Architecture, Podgorica, Montenegro \\ Veljko Radulović \\ University of Montenegro, Faculty of Architecture, Podgorica, Montenegro \\ Ema Alihodžić-Jašarović \\ University of Montenegro, Faculty of Architecture, Podgorica, Montenegro \\ Vera Murgul \\ St. Petersburg State Polytechnical University, Saint-Petersburg, Russia
}

The paper provides an overview of the role of light (both daily and artificial) in façade treatment on the examples of contemporary interpolations. Design of façade envelope with regard to the characteristics of light (natural and artificial) ranges from the response to natural elements of the context, via treatment of light as substance, the role of light in constructing and transforming architecture, the role of light in attracting attention, to the communicative and interactive role of light in media towns. The use of classical elements has been analysed and transposition of traditional or natural language has been indicated, as universal response to the conditions of locality, by transforming their formal possibilities using new technological achievements. It has been shown that such architecture may be well interpolated and returned to the place, related to the events in space, and it may contribute to the change of image of our towns, in general.

Key words: Light as a material, Facade, Interpolation, Media facades, Daylight

\section{INTRODUCTION}

The form of a town is first of all the expression of ... historical and physical continuity" [Radović, 2009]. The uniqueness and authenticity of architecture, which represent the accumulation of everything composing genius loci and zeitgeist in which it occurs, stem from the viewpoint that architecture may be examined only in relation to the context of its historical development. Therefore, urban past should represent the preparation for entrance into the future.

"Town is an organism not resistant to various diseases and today they are almost incurable. Town is never final and completed, but an active organism susceptible to permanent alterations. We architects have to do our best so that the spaces of life of citizens make functional, cosy, human-oriented and imaginative. In this way, we would return the depts to the spaces of our living" [Kolacio, 1978]. Urban growth, encouraged by the strength of global economic power, significantly influences the change of urban identity, which considerably conditions the sustainability of the town and traces its future development di- rections [Alihodzic Jasarovic, E, 2015]. The level of randomness of a newly made architecture has been noticed, leading to the architecture outcast from the context and directed towards its destruction and negation. "Such desaturation does not mean that we will leave intangible or unordered spaces. Building should be carried out so that new functional and aesthetic combinations may endlessly enrich by conserving, establish by preserving, protect life heritage by not reducing the town to a museum or monumental cemetery, what has always been included in the town, but what it will never be" [Derrida, 1992].

It is not easy to develop architecture within the existing developed urban fabric. Disregarding hermetic viewpoint related to history and historical heritage as dominant and appreciating the needs of the town for further development and extension, there is a question of how to perform new articulation of space by the means of light, and solves requests based on the preservation of compositional - artistic qualities, which represent the sedimentation of cultural - historical trends. 


\section{ROLE OF CONTEMPORARY INTERPOLA- TIONS IN URBAN CONTEXT}

"Interpolation process or the process of integration of urban events, as well as regularly defined physical architectural interpolation - simultaneous and parallel strategies of urbanism system, simultaneously contributes to the construction of a town"[Mrduljaš, 2011]. Interpolation appears as the most active type of urban recovery, and it has been made from French word "interpoler", which means: to embed - insert a new building into the already existing historical urban unit, which then becomes "aesthetic veneer" of newly built structures. According to Bernard Tschumi, in order to achieve harmonious and aesthetically appropriate building in historical surrounding, it is necessary to explore the relationship among: concept, context and content [Tschumi, 2005]. This relationship may move from indifference, reciprocity to absolute conflict, so it is suggested to architects to direct their activity more towards research and materialization of concept, rather than towards the shaping.

Stratification and complexity of historical urban context should be one of key factors taken into consideration during contemporary interpolations in space. Quality parameters and legitimacy of interpolation which influence urban form and typology of heritage, as well as the lessons for contemporary design have been considered through the following [Idrizbegović-Zgonić, 2009]:

1) Valorization of the existing: objective valorization (building/structure has to have rational relationship towards natural, climate and morphological conditions, create functionally rational and useful space and activate surrounding space as integral part of the building) and subjective valorization (it estimates the value of the valued and defines author's personal affinity towards certain ambience);

2) Identification with space - attempt of an author to reach the core of spatial relationships in the ambience. Building/structure visually and aesthetically has to create quality relationships with environment in measures, proportion, volumes and materials by creating continuity, emphasizing the existing characteristics of the space. Immediate contact of historical context and newly designed building has been frequently solved via: harmonization of rhythm of façade apertures, materi- als, masses, volumes, structural grids, style harmonization, transposition and the like;

3) Ownership of expression - manner of expression or the language of shapes has to be in line with the time of building, as architecture is the reflection of its time. It has to represent generator of innovativeness and positive universal characteristics of architecture. Interpolated building/structure has to comply with metaphysical aspects of the context (memories of a place, ambience ...) and use phenomenology during the design of a space.

\section{DESIGN OF BUILDING ENVELOPE AS THE INTERPOLATION ELEMENT}

The era of technology and application of new materials very frequently radically breaks ties with tradition, place and identity. Architecture has radically transformed its formal possibilities by technological progress and design of new programmes which enable the calculations of complex structures and forms. In the mid-nineties, new ways of digital production of images and simulation of objects influenced also the manner of expression in architecture, which transforms architectural image into event. As such, architecture has started to break ties with the spirit of place, while stratification and complexity of historical context have become neglected. Technology tends to standardize architecture, make it uniform, which results in globalization of architectural thought. Accordingly, the nature of contemporary architecture is not characterized by adapting to historical urban context, so such new buildings/structures are frequently in opposite relationship with context, ignoring and confronting it.

The root of the word "façade" is related to Latin word "facies" (face). Façade represents the face of the building and the component by which the building is most directly identified. Contemporary architecture is increasingly oriented towards the treatment of façade shell as independent element, by adding multi-layer element into the meaning and functions. Façade does not represent the "border" anymore, which closes certain volume, but it represents the tie between the nature, environment, building and interior volume [Ćuković Ignjatović, 2010]. The number and multi-layer element of functions undertaken by the façade, technical characteristics it encom- 
passes, additional complex meanings and interpretations intertwined with these processes, require critical view of physical, functional and symbolic border of the façade, and aperture in general. "New technologies, materials and their possibilities in use provided encouraging motive to architecture, as conceptual programmes may ensure their existence in future.... Observing the envelope of the building as the element of building interior with the environment "both in technical and semantic terms, as one-of-a-kind envelope which, in contemporary architecture, represents a complex system which defines and articulates the mentioned topics in layers" [Ugljen Ademović, 2012]. The envelope of the building, by development of contemporary technological solutions, has been treated as independent element with regard to the building structure, so its role is of paramount importance in contemporary interpolations. Design of façade envelope with regard to the characteristics of light (natural and artificial) ranges from the response to natural elements of the context, via treatment of light: as substance, the role of light in constructing and transforming architecture, the role of light in attracting attention, to the communicative and interactive role of light in media towns. Unlike numerous examples of mega sculptures, the examples of fetish abstraction, breaking ties with continuity of the place, correct treatment of façade shell may contribute that the space be experienced through all senses, emphasizing emotional character of the building and harmony between façade envelope and impression of built space, by the means of light.

\section{THE LIGHT IS SHAPING ARCHITECTURE}

This chapter analyses natural light, pointing at formal solution of natural light and its benefits, and develops the architectural concept whereas "the form follows the Sun" shaping itself depending on local climate parameters. All climate parameters applicable to topography are also valid for the existing urban fabric, thus according to Frampton [Foster, 1983], the building must be designed considering unpredictable climate and weather characteristics of sunlight at a given location, which "the sensitive modulation and incorporation of such factors must almost by definition be fundamentally opposed to the optimum use of universal technique. This is perhaps most clear in the case of light and climate control. The generic window is obviously the most delicate point at which these two natural forces impinge upon the outer membrane of the building, fenestration having an innate capacity to inscribe architecture with the character of a region and hence to express the place in which the work is situated" [Foster, 1983]. Nowadays the most comfortable and pleasant spaces are those that allow the designer and users to establish control over the lighting. Such spaces wherein the object of interest is adequately emphasized by adjusting the source of light will be freed from visual discomfort, and the need to introduce artificial light will be minimized. The genesis of design principle "the form follows the Sun" is shown in the examples in Figures 1-3. With trapezoids windows Breuer managed to control light intrusion in the interior volume subject to the complexity of museum exhibition lighting. Using the form of inverted ziggurat without openings, the building is entirely "closing" towards the Sun (Figure 1, a)). The development of glazing materials and excessive solar radiation protection systems enabled the architect to shape the object and "open" it towards the Sun. Multitude of dynamic visures of façade surfaces and uneven height arrangement of volumes, together with the Sun, make that the Sun turns the game of light and shade into the key element that reveals the distribution and shape of building's monolete volumes. Volumes are covered with metal grids, which act as light filters, where the light is refracted and gives the façade a shimmering outlook. (Figure 1, b)). Angular "fins" in aluminum frames on the sides of the windows stick out from reinforced concrete structure. They have been threedimensionally designed as to provide protection from negative solar radiation, overheating and precipitation [dezeen.com] (Figure 1, c)).

The project of the extension of Tate Modern museum in London has achieved complementary dialogue with the existing historical context, by emphasizing the existing, by balance in tactile material, architecture which returns the "impulse to touch". Herzog \& de Meuron architects have avoided shocking interventions which would alter the image of the town. They tried to harmonize the new building with original aesthetics and artistic values of the original building. Correct disposition of apertures on the façade encourages symbolic value and discovers uniqueness and attractiveness of the form. This example illustrates that the "significance of the tactile is found in the fact that it may be decoded only in 
terms of the experience: it may not be reduced to mere information, to representation or simple apparent evocations which change the absence of presence“ [Foster,1983].

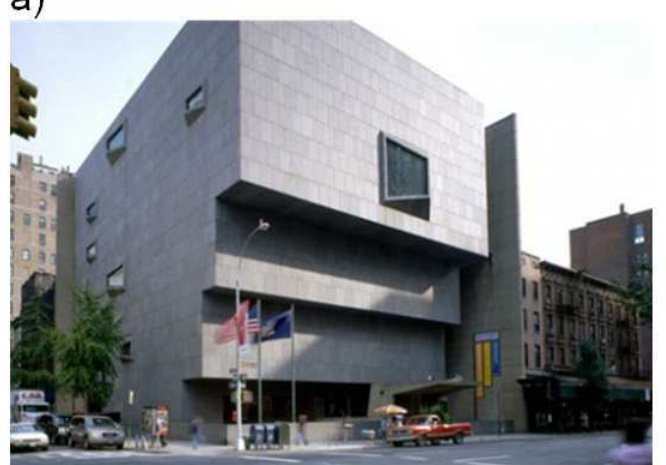

b)

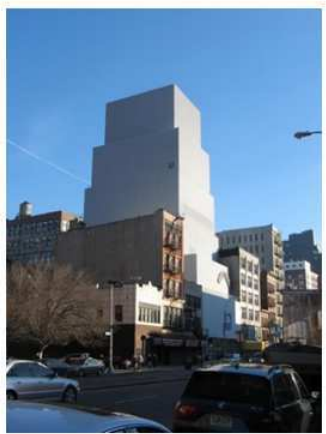

c)

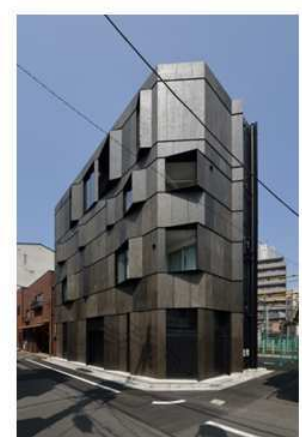

Figure 1: a) 1966: Whitney Museum - Marcel Breuer, New York, USA, b) 2007: New Museum of Contemporary Art - Sanna, New York, USA, c) 2013: KURO Building - KINO Architects, Tokyo, Japan
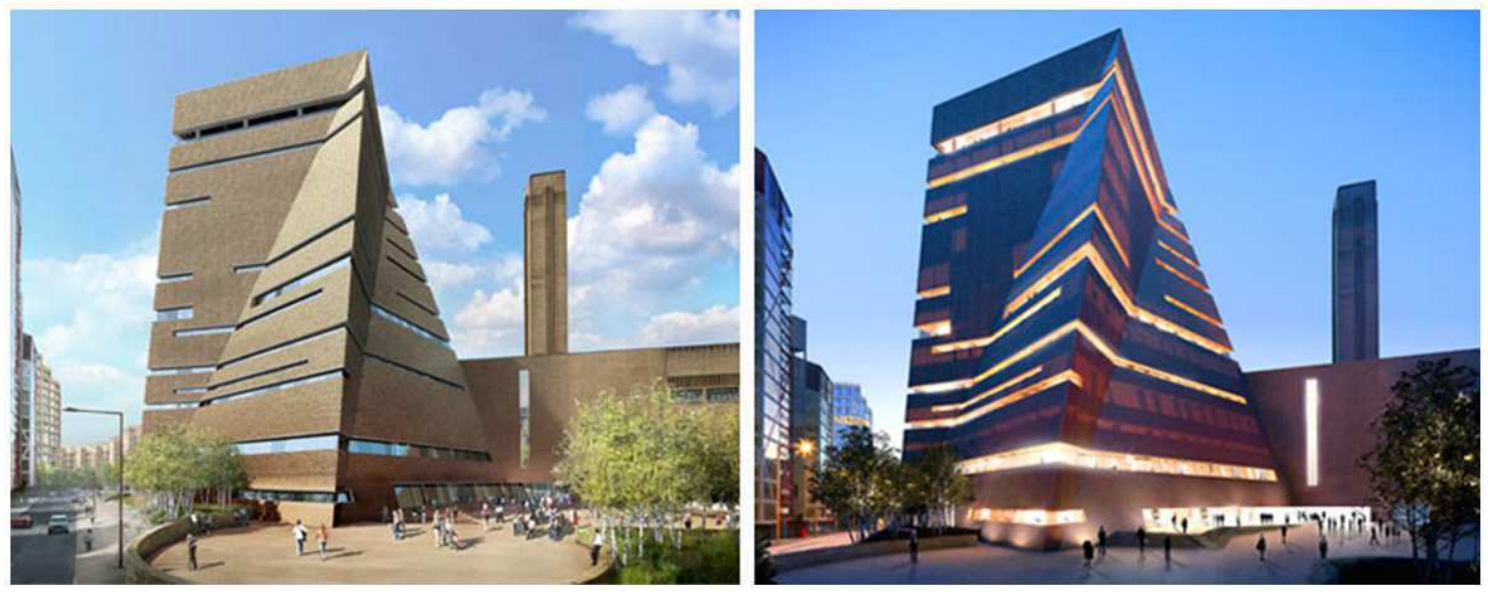

Figure 2: Proposal design for expansion of Tate Modern museum to officially open in 2016 - Herzog \& de Meuron, London, UK

a)

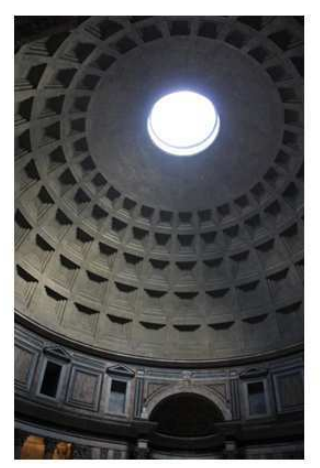

b)

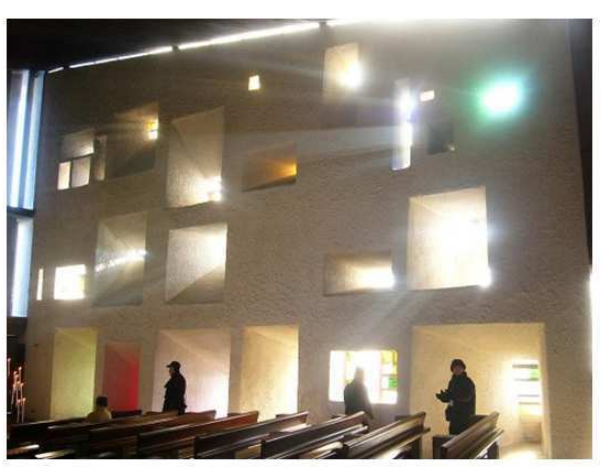

c)

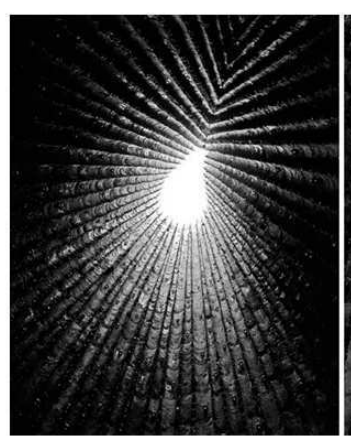

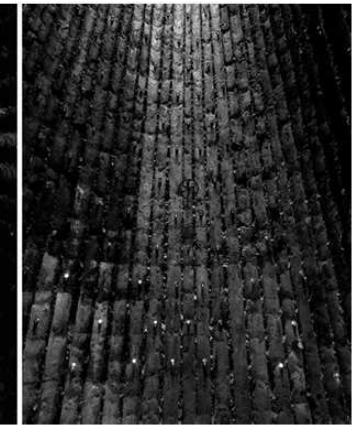

Figure 3: Light defined as a material a) Dome of the Pantheon, b) Le Corbusier's chapel at Ronchamp, c) Chapel Klaus, Pater Zumthor

\section{THE LIGHT IS CREATING AN ATMOSPHERE OF ARCHITECTURE}

"Architecture is the masterly, correct and magnificent play of masses brought together in light. Our eyes are made to see forms in light; light and shade reveal these forms; cubes, cones, spheres, cylinders or pyramids are the great primary forms which light reveals to advantage; the image of these is distinct and tangible within us without ambiguity. It is for this reason that these are beautiful forms, the most beautiful forms" 
[Le Corbusier, 1923]. Architecture is determined by light. The light reveals the architectural form and meaning, making it distinctive and universal. "Light should be understood as substance... We could say that traditional or classic architecture has been always insisting on the durability of architectural design. More and more we try to work with concepts such as programming of complex architectural effects on the same building. Playing with transparency always implies playing with material, so that the building could have multiple "faces". If we work with glass, it is possible to programme what we will see" [Mrduljaš, 2008].

Dome of the Pantheon - a sophisticated lighting effects emphasize form (Figure 3, a)), Le Corbusier's chapel at Ronchamp - light emphasizes haphazard arrangement of windows forming a matrix and emphasizing the mass (Figure 3, b)), Chapel Klaus, Pater Zumthor - the play of light and materials, light emphasizes texture (Figure 3, c)) [16].

Transforming architecture by the means of artificial light, the emotional experience of the observer could be "falsified" thus making the architectural identity of the building more complex. Skillful combination of colour and artificial light could affect the relationship building - observer, in the following ways:

1) the colour of the light arouses emotions in the observer, emphasizing and enhancing architecture, "falsifying" emotions in the object - viewer relationship;

2) the lighting makes the architectural concept adjustable allowing a 24-hour "life" of the object and its interaction with the environment;

3 ) the lighting substitutes classical façades with new experiences, emphasizing the play of colours and giving the completely new night outlook to the neutral building shell;

4) it emphasizes the tactility and „functioning like an extension of the sense of sight, the eye - like a sense of touch operating at a distance" [zumtobel.com/façade];

5) the dynamic nature of lighting and intensive colours make the object perceived from a distance, attracts attention and observer's desire to explore it or "communicate" with it.

Light can affect the emotional experience and attract the attention. Coloristic culture is a name for a phenomenon which bares emotional, aesthetic and semantic information (Also known as synesthesia - "union of the senses").

"Transformation of town spaces by the introduction of coloured structures is one of the ways to express expert attitude towards public town space. Transformation of the condition of a certain monochromatic environment into a polychromatic one may be best understood in the context of its development"[Vasiljević Tomić, 2007].

Radical intervention of transformation of form i.e. structure has been recognized on the example of the Museum of Modern Art in Malmö (Figure 4). Extension of the museum was designed so as to emphasize the arrival new museum contents, to represent a rare opportunity for the creation of new "nodes" within constructed town structures and to transpose the materialization of industrial brick of nearby buildings into the sheath of highest climate and security performances.

The alignment of colour with historical urban context, the achievement of coloristic and volumetric harmony, ensured the conditions for the creation of "spatial values: intelligibility, emotionality and behavior" [Vasiljević Tomić, 2007].

In the pursuit for coloristic harmony of town ambience, it may be talked about monochromatic interventions for the sake of achieving coexistence of the new and the inherited.

These interventions imply the preservation of values of historical urban context. "One and the same colour, which has appropriate physical characteristics, evokes different feeling" [Idrizbegović-Zgonić, 2009]. In the example of the headquarters of "Dolce \& Gabbana" company in Milan (Figure 4 [16]), coloristic harmonization of space has resulted in the increase of quality of town ambience, by complying with spatial and social requirements.

Entirely modern "ode to classicism" has managed to contribute to aesthetic expression and pleasant psychological climate, by fostering sophisticated and recognizable style.

The simplicity of architectural details, economic transparent materials which make the building transparent and extrovert, both during the day and during the night - by the use of neutral light tones, may be considered a good formula for successful interpolations in historical urban contexts. 
a)

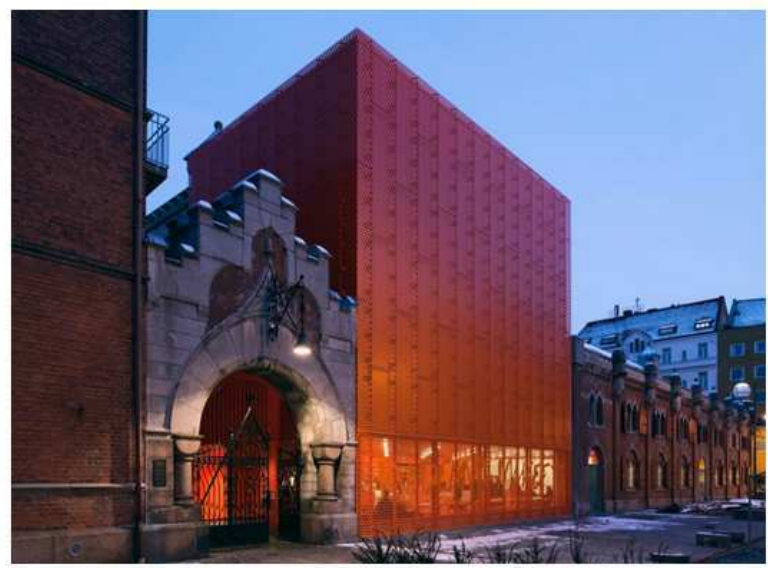

b)

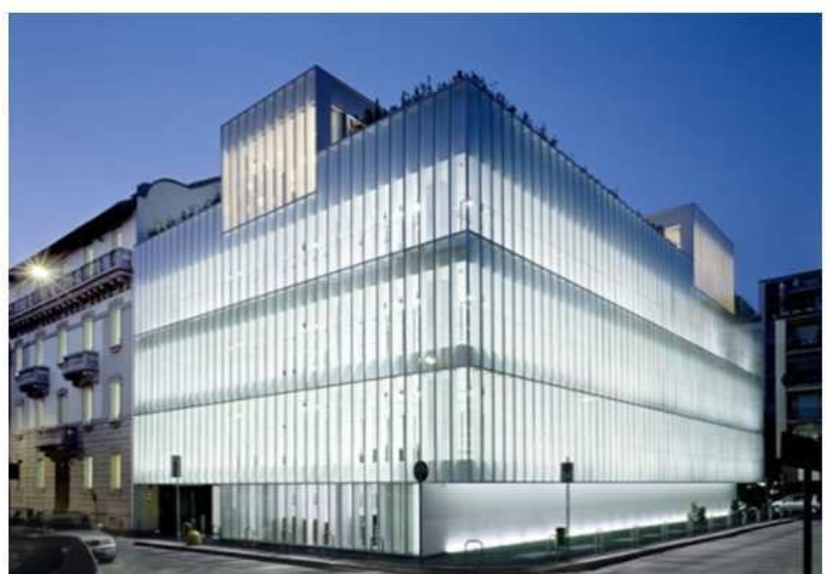

Figure 4: a) 2009: Moderna Museet Malmö - Tham \& Videgård Arkitekter, Malmo, Sweden, b) 2006: Dolce \& Gabbana Headquarters - Studio Piuarch, Milan, Italy

Achievements in the development of technologies and materials have encouraged architects in their conceptual programmes, so they have found a model for architectural works to exist during the night, by insisting on their dual nature and recognisability: during the day - by interesting volume, during the night - by light-transparent façade. Owing to the development of LED technologies, façade is now able to exist unobtrusively during the day, while during the night, when it is not possible to view urban environment, it is transformed into new spatial values. The permanence of change in the example of
Museum of Art in the town of Celle (Fig. 5 [18]) may be interpreted almost physically, while the light integrated into the envelope of the building may be read as its "second skin". The first 24hour museum in the world offers the concept of "incessant art", in which visitor becomes the part of interactive scenario. This building respects both apparently opposite principles: "respect the evolution of timeless values and sensations as a mirror of the moment" [Ugljen Ademović, 2012], respecting three main parameters of the form: dynamic, structure and meaning.
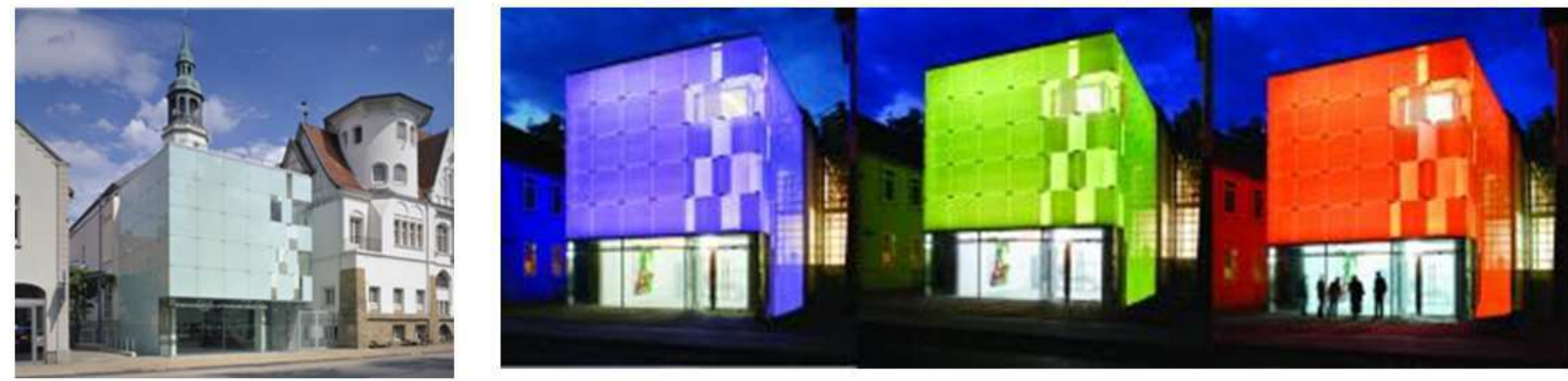

Figure 5: 2006: Museum of Art - Ahrens Grabenhorst Architekten BDA Hannover

\section{INTEGRATIVE ROLE OF LIGHT IN ARCHITECTURE}

"Media façades" are defined as surfaces, envelopes or membranes where the integrated visual electronic programme functions as the "public media". The Latin origin of the word has the meaning of convertibility, flexibility and reaction to external influences (mediaarchitecture. org). The role of façade as the media is based on four characteristics: interactivity, multimedia, connectivity and generativity [a-theory.tuwien. ac.at]. These types of facades have a tendency to transform experience into new forms. Media days are endless, and the present is subject to commercial contents. Auto-active and interactive video contents filter the content of marketing facilities and influence the perception of a passerby. Today artificial lighting is vital for the society because it has been exploited as a medium for launching social transformations [Derrida, 1986]. The award-winning and socially recognized author of Croatian architectural practice, Krešimir Rogina, in his article "From a Visual Civilization 
to an Audio Tactile Culture" (Original title: Arhitektonski fokus Krešimira Rogine (Iz vizuelne civilizacije $k$ audio taktilnoj kulturi) states that "architecture in digital age is definitely no longer the play of volumes in the light, but the play of digital information in space" [Rogina, 2011]. "Hypermultimedial" buildings provide information by means of communication with the environment reconciling the schizophrenic ambivalence of physical and virtual reality. Buildings are identified with billboards, and while sound and light sensations occur in the structure of the building's envelope, the space inside of the volume becomes almost unadaptable for dwelling. New "virtual" city spaces disrupt the intimacy and render false aspirations of the social community. The narrative structure of traditional building envelopes now becomes an autonomous element that allows us to be in many places at the same time. The city becomes the scene for urban interactions of media façades, the place for virtual dialogue. Façades are treated like "building land" and collective action place. The relationship between the passer-by and envelope is no longer only physical and visual, but the place for emotional focus and interactive drama. These urban decorations cannot be treated as architectural solutions. Large screens (billboards) are not aimed at cultural and artistic awareness, but acquire strictly commercial characteristics, and become the means for demonstrating the power of gigantic corporations. Outdoor cinemas, large displays are treated like real estate, relocating the issues of everyday life into cyberspace. They represent the source of light pollution that is the product of light illuminations in cities. a)

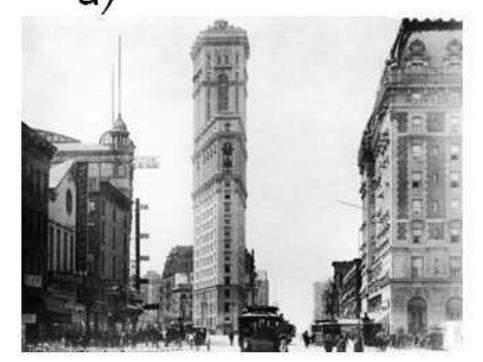

b)

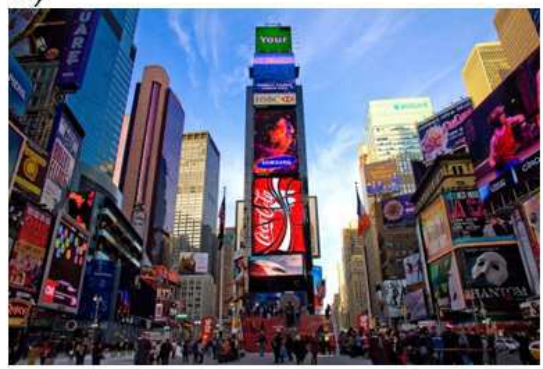

c)

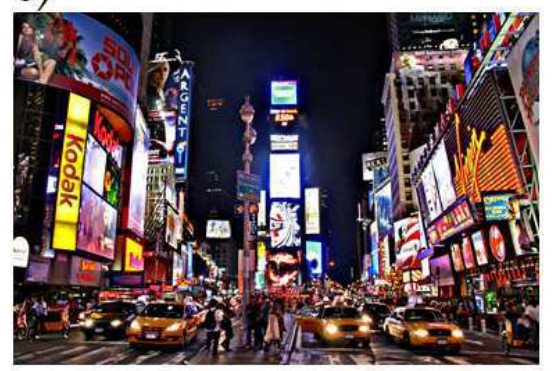

Figure 6: a) Times Square 1904 - before the era of media façades, b) Times Square - during the day, c) Times Square - during the night [19]

In the 2000 Charter of Zurich "interactivity" was classified into nine points of "new architecture". Interactivity is defined as: "closely related to the development of new intelligent materials, not only responding to the environmental conditions but also conditioning their structural changes and adjustments" [Rogina, 2011]. The fact that cities like New York are considered media cities is truly justifiable. Reference points in such cities are no longer defined by streets, corners and squares, but by media façades or ensemble of buildings designed in the spirit of media technology. This type of public spaces replaced the former public spaces with classic aesthetics, becoming the spaces of permanent circulation, so it appears like the implemented screens are competing to attract more attention and acquire a dominant position in the sound and colour drama. Cities like New York and Tokyo now "speaks, it emotes, at night as in the day" [Lefebvre, 2004]. Buildings expand into infinity, with only one aim, to provide more space for marketing activities. Buildings and their aesthetic characteristics are not perceived due to their covering with screens, so the interpolation in such urban contexts is based on the level of screen layering.

\section{CONCLUSION}

Is there any successful model which guarantees a quality compromise? As stated at the beginning, the only idea is that tradition phenomenon is accepted as unchangeable situation, while the content made by the method of replication, citation and transcription is the only one considered as successful. Usually in pursuit for timeless solutions, we turn to past, seeking for the solutions in "tested" historical images. Such approach reflects the burden of the past, and it may rather easily lead to dual adversity: "the past and tradition are treated as static phenomena deprived of development and frozen in certain moment, or provisional interpretation of heritage is created, indulged to utterly subjective attitude of the author, which frequently leads to misunderstand- 
ing" [Petrović, Rašković, 2011].

On the other hand, the idea is that completely new spatial and visual forms, established for the first time in a visual environment, should express the values in time they occur, as well as be their trace of future. Diversity of built contents which make the whole illustrates the situation described by Geoffrey Bennington as the "paradox of the future of the past" by which the rules of creating a unit are established during its creation, so that the work has a character of event [Bennington, 1984]. Bernard Tschumi in his text Architecture and Transgression says the following: "Architecture of pleasure is found where concept and experience of space abruptly coincide, where architectural fragments collide and merge into ecstasy, where architectural culture is endlessly deconstructed, and all the rules are breached. There is no metaphoric end, only uneasiness and misbalance of expectations. It denies everything - typologies, morphologies, spatial compressions, logical constructions" [Tschumi, 2005]. The acceptance of such concept requests the appreciation of mutual relations through their differences, for what it is necessary to establish new way of thinking, suitable to today's cultural moment. We find codes in spatial experience, which represent nothing else by spatialization of time, which are exactly the old historical town centres.

\section{REFERENCES}

1) Alihodzic Jasarovic, E., Komatina, D., Paunović Žarić, S., Murgul, V., Vatin, N. (2015): Decentralization as a cause of spatial segregation, Applied Mechanics and Materials, Vols. 725-726, pp 1134-1140.

2) Bennington, G., Massumi, B. (1984): Racionalnost revitaliteta postmoderne, Minneapolis: University of Minnesota Press.

3) Derrida, J. (1992): Générations d'une ville: mémoire, prophétie, responsabilité , Éditions de l'Aube.

4) Foster, H. (1983): The Anti-Aesthetic essays on postmodern culture (Kenneth Frampton: Toward a Critical Regionalism: Six Points for an Architecture of resistance), Buy Press, New York.

5) Idrizbegović-Zgonić, A. 2009: Challenge of set frames, University of Trieste, Italy.

6) Kolacio, Z. (1978): Vizije i ostvarenja, Zagreb.
7) Le Corbusier, (1923): Vers une architecture, Paris

8) Lefebvre, H. (2004): Rhythmanalysis Space, Time and Everyday life, Continuum, New York, pp. 46

9) Mrduljaš, M. (2008): Singularni objekti - athitektura i filozofija, Birotisak doo, Zagreb

10) Radovic, R. (2009): Forma grada. Osnove, teorija i praksa, Građevinska knjiga, Beograd.

11) Rogina, K. (2011): Arhitektonski fokus Krešimira Rogine (Iz vizuelne civilizacije $\mathrm{k}$ audio taktilnoj kulturi), Meandar Media, Hrvatska

12) Tschumi, B. (2005): Event - Cities 3 (Concept vs. Context vs. Content), MIT Press

13) Ugljen Ademović, N. (2012): Kritika - stimulans arhitektonskoj ideji, Dobra knjiga, Sarajevo

14) www.mediaarchitecture.org/conf/253/ (retrieved on November 22th, 2015)

15) www.a-theory.tuwien.ac.at/Profiles/Oliver (retrieved on November 22th, 2015)

16) www.zumtobel.com/façade (retrieved on November 22th, 2015)

17) www.archdaily.com (retrieved on November 22th, 2015)

18) www.kunst.celle.de (retrieved on November 22th, 2015)

19) www.presseportal.de/pm/62409/1093987/ celle-z-hlt-zu-den-12-besten-in-der-republik (retrieved on November 22th, 2015)

20) https://playingintheworldgame.wordpress. com/2012/09/17/ (retrieved on November $\left.22^{\text {th }}, 2015\right)$

Paper sent to revision: 03.02.2016.

Paper ready for publication: 08.03.2016. 


\section{SVETLO OTKRIVA ARHITEKTONSKU FORMU - ULOGA SVETLA U SAVREMENIM INTERPOLACIJAMA}

Sanja Paunović Žarić, Univerzitet Crne Gore, Arhitektonski fakultet, Podgorica, Crna Gora Veljko Radulović, Univerzitet Crne Gore, Arhitektonski fakultet, Podgorica, Crna Gora Ema Alihodžić Jašarović, Univerzitet Crne Gore, Arhitektonski fakultet, Podgorica, Crna Gora Vera Murgul, Državni Politehnički Univezitet, St. Petersburg, Rusija

Projektovanje fasadnog omotača u odnosu na karakteristike svetla kreće se od odgovora na prirodne elemente konteksta, preko tretmana svetla kao materije, uloge svetla u konstruisanju i transformisanju arhitekture, uloge svetla u privlačenju pažnje, do komunikativne i interaktivne uloge svetla u media gradovima. Analizirano je transponovanje tradicionalnih elemenata, univerzalnog odgovara na uslove lokaliteta, transformišući njihove formalne mogućnosti upotrebom novih tehnoloških dostignuća. Kao takva, arhitektura može interpolirati i vratiti mestu i odvijanjima u prostoru.

Ključne reči: Svetlo kao materijal, Fasada, Interpolacija, Media fasade, Dnevno svetlo 